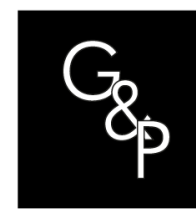

\title{
How to fight food waste in university restaurants?
}

\section{Como combater o desperdício de alimentos em restaurantes universitários?}

\author{
Lucas Rodrigues Deliberador $^{1}$ (D), Aldara da Silva César ${ }^{2}$ (D), Mário Otávio Batalha ${ }^{1}$ (1) \\ ${ }^{1}$ Universidade Federal de São Carlos - UFSCar, São Carlos, SP, Brasil. E-mail: deliberadorlucas@gmail.com; \\ dmob@ufscar.br \\ ${ }^{2}$ Universidade Federal Fluminense - UFF, Volta Redonda, RJ, Brasil. E-mail: aldaracesar@id.uff.br
}

How to cite: Deliberador, L. R., César, A. S., \& Batalha, M. O. (2021). How to fight food waste in university restaurants?. Gestão \& Produção, 28(2), e5415. https://doi.org/10.1590/1806-9649-2020v28e5415

\begin{abstract}
About one-third of the world's food production is lost or wasted annually at different stages of food supply chains (FSCs). Food loss usually occurs in the early stages of FSCs, while waste is more prevalent in their final stages. Thus, the main objectives of the present study were to investigate the causes of loss and waste, as well as strategies that can minimize them. Decreasing food waste in collective catering organizations, including university restaurants, is situated in the context of these concerns. In order to contribute to this discussion, the authors investigated the causes of wastage in university restaurants and possible interventions recommended in the literature to reduce it. A search considering the "food waste" and "university restaurant" constructs in five different databases found 352 publications related to the theme, of which 21 supported to answer the two questions that guided this search: Q1: "What are the causes that contribute to food waste in university restaurants?" and Q2: "What are the interventions that can be or are used in university restaurants to reduce food waste?" The literature search identified 13 causes (portion size; quality; price; emotion; palatability; preparation/cooking; menu; time; satiety; storage; service; overbuying; security) and 14 possible interventions (campaigns; trayless systems; waste management; portion size; quality; changing menus; planning; preordering; charity/donations; nutritional information; coercion; changing the dishes; preparation/cooking; storage). From this perspective, the present article provides a holistic view of food waste in university restaurants, in order to guide mitigation interventions and future research on this theme.
\end{abstract}

Keywords: Systematic literature review; Plate waste; Factors; Actions; Causes; Interventions.

Resumo: Cerca de um terço da produção mundial de alimentos é perdido ou desperdiçado anualmente em diferentes estágios das cadeias de produção agroalimentar (CPA). Geralmente, as perdas de alimentos acontecem nos estágios iniciais das CPA, enquanto o desperdício está mais presente nos estágios finais destas cadeias. Assim, os principais objetivos do presente estudo foram investigar as causas de perdas e desperdícios, bem como estratégias que possam minimizá-los. A diminuição do desperdício de alimentos em organizações de alimentação coletiva, incluindo restaurantes universitários, situa-se no contexto destas preocupações. Para contribuir com essa discussão, os autores investigaram as causas do desperdício em restaurantes universitários e possíveis intervenções recomendadas na literatura para reduzi-lo. Uma pesquisa considerando os construtos "desperdício de alimentos" e "restaurante universitário" em cinco bases de dados diferentes encontrou 352 publicações relacionadas ao tema, das quais 21 apoiaram responder as duas questões que nortearam essa busca: Q1: "Quais

Received Aug. 28, 2019 - Accepted Oct. 28, 2020

Financial support: This study was financed in part by the Coordenação de Aperfeiçoamento de Pessoal de Nível Superior - Brasil (CAPES) - Finance Code 001. 
são as causas que contribuem para desperdício de alimentos em restaurantes universitários?" e Q2: "Quais são as intervenções que podem ser ou são usadas em restaurantes universitários para reduzir o desperdício de alimentos?" A pesquisa bibliográfica identificou 13 causas (tamanho da porção; qualidade; preço; emoção; palatabilidade; preparação/cozimento; composição do cardápio; tempo; saciedade; armazenamento; serviço; compras em excesso; e segurança) e 14 possíveis intervenções (campanhas; remoção de bandejas; gerenciamento de resíduos; tamanho da porção; qualidade; mudança de cardápio; planejamento; pré-encomenda; caridade/doações; informações nutricionais; coerção; mudança de pratos; preparação/cozimento; e armazenamento). Nessa perspectiva, o presente artigo fornece uma visão holística do desperdício de alimentos em restaurantes universitários, a fim de orientar intervenções de mitigação e futuras pesquisas sobre o tema.

Palavras-chave: Revisão Sistemática da Literatura; Desperdício em pratos; Fatores; Ações; Causas; Intervenções.

\section{Introduction}

Food insecurity has increased worldwide (Warshawsky, 2011), and to fight against it, the United Nations included food security as one of the 17 Sustainable Development Goals (SDG) set by Agenda 2030 (United Nations, 2015). It is estimated that 821 million people are already undernourished (FAO, 2018). Conversely, while some people are struggling to access staple foods (Schneider, 2013; Douglas, et al., 2015; Purdam et al., 2015); food is also been wasted worldwide (Schneider, 2013).

About 1.3 billion tons of food are lost or wasted annually, which is equivalent to $30 \%$ of world food production, and represents a monetary value approaching $\$ 750$ billion (FAO, 2017). Besides economic losses (Graham-Rowe et al., 2015; Thyberg \& Tonjes, 2016), wasted food also generates environmental impacts due to the natural resources used in its production, and the emission of greenhouse gases (Williams et al., 2015). In addition, wasting food in societies in which people are still going hungry evidences lack of respect for food by affluent societies (Schneider, 2013), since food could be made available to people in need (Thyberg \& Tonjes, 2016).

This context has raised questions about how to reduce food losses and waste in agrofood production chains (Raak et al., 2017). Food loss and waste along agro-food production chain represent misused resources. As resources (land, energy, water, agricultural inputs, etc.) are limited in nature, they must be applied efficiently and sustainably (Beretta et al., 2013).

However, an in-depth understanding of the factors that most influence food loss and waste is necessary in order to then propose solutions to the problem (Raak et al., 2017). There are different causes of food waste, which are strongly influenced by the socioeconomic context of a given country and the organization of its food system (Gustavsson \& Stage, 2011). The amount of food that is lost or wasted can be influenced, for example, by levels of income, industrialization, and development (Chalak et al., 2016).

While the debate about food waste is of global importance, developing countries tend to face relatively greater challenges, especially in food waste management, given the lack of selective collection and historical data that hamper planning of mitigation interventions (Thi et al., 2015).

Developed countries usually have higher rates of food waste (Martin-Rios et al., 2018). Per capita food waste in developed regions, such as Europe and North America, amounts 
to $95-115 \mathrm{~kg} / \mathrm{year}$, while in developing regions, such as sub-Saharan Africa and South and Southeast Asia, this value is about 6-11 kg/year (Gustavsson et al., 2011).

However, recent studies have shown that food waste is a threat in developing countries as well. According to Porpino et al. (2015) and Porpino (2016), Brazilian households discard considerable amounts of food due to cultural factors: abundant food stocks are highly valued, and can convey ideas of wealth, hospitality and affection.

It should be noted that the concept of food loss and wastage is often used in the scientific literature to identify food for human consumption that is subsequently discarded, lost, degraded or contaminated (Gustavsson et al., 2011; Girotto et al., 2015). Even though there is no consensus on terminology, the present article considers losses that occur upstream of food supply chains, i.e., inadequate agricultural practices, technical limitations, financial and labor constraints, and inadequate infrastructure for storage, processing, and transportation (Gustavsson et al. 2011).

Food waste has been investigated more often at the consumer stage, where collective feeding services are gaining prominence (Parfitt et al., 2010; Birisci \& McGarvey, 2018). In this case, it may be attributed to serving or preparing oversized portions, purchasing excess food, inability to consume food before its expiration date, and difficulty in correctly interpreting the instructions on the labels of packages (Buchner et al., 2012; Katajajuuri et al., 2014; Papargyropoulou et al., 2014).

Out-of-home eating has increased considerably during the last decades and has become relevant in the daily diet (Ferreira et al., 2013). As a result, food services have become a strategy to promote a balanced diet for an increasing number of consumers. However, studies on waste in food services lack accurate data (Sebbane \& Costa, 2018). The present article aims to contribute to this discussion by investigating the causes of waste in university restaurants and the possible interventions recommended in the literature. From this perspective, one of the main contributions of this work is to provide a holistic view of food waste in university restaurants, in order to guide future research on this theme.

\section{Food services and waste: the case of higher education institutions (HEls)}

Food services are composed of businesses and people involved in the preparation of meals and beverages for non-home consumption (Pirani \& Arafat, 2016). These services can be divided into private and public.

The private sector of food services consists of businesses that aim to maximize their profit, such as restaurants, fast food restaurants, pubs, hotels, etc. The public sector differs in that profit is not the main objective; rather, it is the provision of services, such as providing food in schools, hospitals, prisons, military installations, etc. (Table 1) (WRAP, 2013). 
Table 1. Food services: description and examples.

\begin{tabular}{|c|c|c|c|}
\hline Sector & $\begin{array}{l}\text { Type of food } \\
\text { service }\end{array}$ & Description & Examples \\
\hline \multirow{6}{*}{ 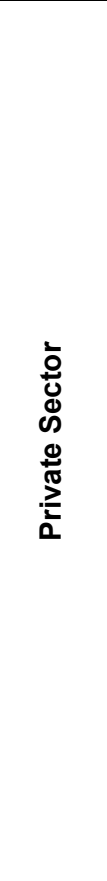 } & $\begin{array}{l}\text { Commercial } \\
\text { restaurants }\end{array}$ & $\begin{array}{l}\text { Establishments with food services for } \\
\text { consumption in the environment; the } \\
\text { users pay after finishing the meal. }\end{array}$ & $\begin{array}{l}\text { Japanese and Chinese } \\
\text { restaurants, bistros, self- } \\
\text { service restaurants, a la } \\
\text { carte etc. }\end{array}$ \\
\hline & $\begin{array}{l}\text { Fast-food } \\
\text { restaurants }\end{array}$ & $\begin{array}{l}\text { Establishments with food services for } \\
\text { consumption inside or outside the } \\
\text { environment; users pay at the time of } \\
\text { ordering the meal. }\end{array}$ & $\begin{array}{l}\text { Fast food restaurants, } \\
\text { bars, cafeterias etc. }\end{array}$ \\
\hline & Pubs & $\begin{array}{l}\text { Establishments where services are } \\
\text { mostly related to the supply of } \\
\text { beverages. Food service accounts for } \\
\text { less than } 50 \% \text { of their business. }\end{array}$ & $\begin{array}{l}\text { Pubs, discotheques, } \\
\text { bars etc. }\end{array}$ \\
\hline & Hotels & $\begin{array}{l}\text { Establishments that provide } \\
\text { accommodation. Food service accounts } \\
\text { for less than } 50 \% \text { of their business. }\end{array}$ & $\begin{array}{l}\text { Hotels, hostels, bed and } \\
\text { breakfast } \\
\text { accommodations etc. }\end{array}$ \\
\hline & Recreation & $\begin{array}{l}\text { Establishments in which the focus is } \\
\text { services for leisure. They may contain } \\
\text { restaurants, fast-food restaurants, pubs, } \\
\text { etc. }\end{array}$ & $\begin{array}{c}\text { Museums and galleries, } \\
\text { theaters, cinemas, sports } \\
\text { clubs, on-board services } \\
\text { etc. }\end{array}$ \\
\hline & Buffets & $\begin{array}{l}\text { Feeding of employees in the work } \\
\text { environment, such as companies and } \\
\text { industries. }\end{array}$ & $\begin{array}{l}\text { Restaurants in the } \\
\text { workplace, which are } \\
\text { managed by the } \\
\text { organization or } \\
\text { outsourced. }\end{array}$ \\
\hline \multirow{3}{*}{ 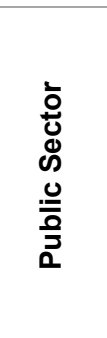 } & Health Care & $\begin{array}{l}\text { Establishments where the focus is on } \\
\text { services for medical care. }\end{array}$ & $\begin{array}{l}\text { Public and private } \\
\text { hospitals, shelters for the } \\
\text { elderly etc. }\end{array}$ \\
\hline & Education & $\begin{array}{l}\text { Establishments where the focus is the } \\
\text { education of children and/or adults. }\end{array}$ & $\begin{array}{l}\text { Nurseries, kindergartens, } \\
\text { primary and secondary } \\
\text { schools, universities etc. }\end{array}$ \\
\hline & $\begin{array}{l}\text { Other } \\
\text { Services }\end{array}$ & $\begin{array}{l}\text { Environments that have food services } \\
\text { financed by the public sector and do not } \\
\text { include medical care and education. }\end{array}$ & $\begin{array}{l}\text { Prisons, armed forces, } \\
\text { police, firefighters etc. }\end{array}$ \\
\hline
\end{tabular}

Reducing costs related to food waste is important for both the public and private sectors. While in the private sector, food wastage diminishes the organizations' profit, it leads to increases in public spending in the public sector, reducing the amount of resources that can be reallocated to the provision of other services (Gardin Alves \& Ueno, 2015). Thus, there is an urgent need to change consumer behavior in both sectors in order to reduce food waste (Stöckli et al., 2018).

The public sector is showing increasing interest in knowing the values of their consumption and food waste (Kuo \& Shih, 2016). Several food service provider institutions have been making efforts to reduce food waste, such as military facilities and university restaurants (Lenahan \& Kirwan, 2001) and hospitals (Williams \& Walton, 2011).

Large quantities of waste usually indicate operational deficiencies, such as undesirable food quality, wrong portion sizes, inefficiency of menus, etc. (Al-Domi et al., 2011). Universities around the world are estimated to produce some 540 million tons of food waste annually, enough to feed a large number of hungry people (Painter et al., 2016). 
Food waste generated in food services is usually from overproduction, improper cuts and crushing, deterioration, incorrect cooking, etc. One of the main drivers of this problem is the difficulty of calculating the correct amount of food to be cooked, because of the complexity of predicting consumer demand and expectations. As a result, inadequate planning can lead to the generation of excessive inventories and greater waste (WRAP, 2013).

Waste on consumers' plates is usually attributed to serving oversized portions, resulting in food not being eaten. These leftovers are more common in buffets, since these services usually prepare larger quantities of food than necessary, and customers/guests take larger quantities of food than they actually consume (Pirani \& Arafat, 2016).

As a result of the diversification and characteristics of the private and public sectors, it is difficult to describe all the factors that contribute to wasting food. However, studies have contended that the causes can be divided into three main categories: waste during preparation; incorrect management; and leftover food (Parfitt et al., 2010; Pirani \& Arafat, 2016; Beretta et al., 2013; Papargyropoulou et al., 2014).

Sebbane \& Costa (2018) discussed strategies to limit the amount of waste generated during food preparation and consumption in restaurants. According to these authors, the implementation of these strategies is only possible if precise data on the quantity and causes of food waste are established (Sebbane \& Costa, 2018). Different causes can influence waste in university restaurants. These include inadequate meal planning, consumer food preferences, and inadequate training of food workers (Alooh, 2015).

University restaurants are reputed to have high levels of waste (Merrow et al., 2012; Alooh, 2015; Birisci \& McGarvey, 2018). It is important to note that, although HEls were originally created to provide communities with places to create, communicate and disseminate ideas (Wright, 2006; Alooh, 2015), they are increasingly involved in the provision of support services, transport, retail, leisure, food supply, and waste management (Zhang et al., 2014).

According to Byker et al. (2014), university food services represent a sector of great interest for interventions aimed at reducing waste. Consumption waste threatens the primary goal of nutrition in universities, which is to provide students with adequate and nutritionally balanced daily meals (Byker et al., 2014). Moreover, since students of public universities generally eat at university restaurants during the week, great quantities of food are produced and handled, which can represent a significant source of waste (Boschini et al., 2018).

\section{Materials and methods}

Systematic literature reviews (SLRs) involve a comprehensive search of relevant studies on a specific subject, which are evaluated and synthesized according to an explicitly predetermined method. SLRs adopt a replicable, scientific, and transparent process that seeks to minimize research bias by providing an audit of researchers' decisions, procedures, and conclusions (Tranfield et al., 2003). Researchers established criteria for specificity and quality for the selection of studies pertinent to the discussion of a theme (Briner \& Denyer, 2012).

In the present article, the SLR adopted the stages proposed by Tranfield et al. (2003): i) planning, ii) conduction and iii) documentation and results. 


\section{i) Stage I: planning}

Searches were carried out in the Scopus, Web of Science, Scielo and Google Scholar databases to find specific studies in the area that guided resolutions about food waste in university restaurants. The SLR sought to answer the following questions (Phase 1), based on the objective of identifying articles published in periodicals/conferences that deal with food waste in university restaurants:

Q1: What are the causes that contribute to food waste in university restaurants?

Q2: What are the interventions that can be or are used to reduce food waste in university restaurants?

Next, the constructs and keywords that cover the theme were specified, as well as the search expressions. The constructs used in the search were "food waste" and "university restaurant." The keywords were identified in order to insert as many relevant terms as possible. For each construct, an individual expression was created, which was composed of Boolean operators to incorporate different orthographies and synonyms.

Proximity operators (NEAR/5) were used to find 5 words within the specified terms. Next, quotation marks were used to include exact terms, making it impossible for other words to appear between them. Truncation of the words in quotation marks was also included for the two search expressions, in order to find all the derivations from a radical. It is worth mentioning that the two search expressions were elaborated following the same logic process and were defined after a series of tests carried out with the help of specialists in the subject area and two librarians specialized in search strategies in databases. Finally, the two search expressions were unified by the Boolean operator "AND", thus forming the following search expression (SE): ((food NEAR/5 waste OR food NEAR/5 wastage OR "waste of food" OR "food wast*”)) AND (((("college * cafe *") OR ("college* canteen*") OR ("college* restaurant") OR ("facult" cafe *") OR ("facult*

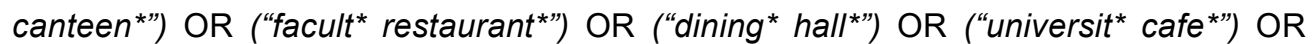
("universit" canteen*") OR ("universit" restaurant*") OR ("educat* sector"))) OR (((college NEAR/5 cafeteria) OR (college NEAR/5 canteen) OR (college NEAR/5 restaurant) OR (faculty NEAR/5 cafeteria) OR (faculty NEAR/5 canteen) OR (faculty $N E A R / 5$ restaurant) OR (dining NEAR/5 hall) OR (university NEAR/5 cafeteria) OR (university NEAR/5 canteen) OR (university NEAR/5 restaurant) OR (education NEAR/5 sector)))).

The Engineering Village, ProQuest, Scopus, Web of Science and Scielo databases were considered due to their relevance; because they provide complete information for the area of study; and due the number of articles returned during the search expression delimitation tests.

Then the selection criteria were defined. Selection bias in systematic reviews may arise when the selection criteria are not clearly established, or they restrict the inclusion of studies in a way that could impair the findings (Nightingale, 2009). In addition, only journal articles, conference articles and in-press articles with readability in full and written in Spanish, English or Portuguese were considered.

The steps in Stage I were inputs into the development of a protocol review (Phase 2) (Appendix A) that guided the study and provided clear guidance for its progress.

ii) Stage II: conduction

The first search resulted in 352 articles distributed in the five databases (Engineering Village $=25$, ProQuest $=145$, Scopus $=137$, Web of Science $=45$, Scielo $=0)($ Phase 3). Then the selection criteria (Phase 4) were applied: i) only articles in periodicals, conference articles and in- 
press articles, resulting in 288 articles (Engineering Village $=23$; ProQuest $=113$; Scopus $=$ 114; Web of Science = 38); ii) only articles written in Spanish, English or Portuguese, totaling 278 articles (Engineering Village $=23$, ProQuest $=107$, Scopus $=114$, Web of Science $=38$ ); and iii) only articles without repetition, totaling 220 articles.

A quantitative analysis of the documents (Phase 5) was done using Start $($ software. It allowed the researchers to apply the weighting criteria, and to establish the priority for reading of the articles according to the number of keywords found in the titles, abstracts and keywords (Table 2).

Table 2. Weighting criteria for quantitative analysis of SLR.

\begin{tabular}{cc}
\hline Evaluation method & Points/Occurrence \\
\hline Keywords found in title & 5 \\
\hline Keywords found in abstract & 3 \\
\hline Keywords found in keywords & 2 \\
\hline
\end{tabular}

The 220 papers selected were read and analyzed with a focus on the titles, abstracts, and keywords, returning a total of 92 studies. To ensure the accuracy of the review process, the authors read the introductions and conclusions of the remaining studies, resulting in 39 selected studies (Phase 6).

In order to evaluate the usefulness and relevance of the selected studies to the objectives of this work (Phase 7), the authors established six criteria questions (C1 to $\mathrm{C6}$ ) (Table 3 ) that were analyzed using quality ranking (Low, Medium and High) as proposed by Nidhra et al. (2013).

Table 3. Quality criteria and rankings applied in SLR.

\begin{tabular}{|c|c|c|c|}
\hline Criteria & Low (+0 points) & Medium (+ 1 point) & High (+2 points) \\
\hline $\begin{array}{l}\text { C1: Did the article } \\
\text { contribute to the literature } \\
\text { about food waste in } \\
\text { university restaurants? }\end{array}$ & $\begin{array}{l}\text { There was no } \\
\text { contribution. }\end{array}$ & $\begin{array}{c}\text { There was little } \\
\text { contribution. }\end{array}$ & $\begin{array}{c}\text { There was a large } \\
\text { contribution. }\end{array}$ \\
\hline $\begin{array}{l}\text { C2: Did the article present } \\
\text { an in-depth theoretical } \\
\text { reference on the subject? }\end{array}$ & $\begin{array}{l}\text { No theoretical } \\
\text { reference on the } \\
\text { subject. }\end{array}$ & $\begin{array}{c}\text { A reasonably } \\
\text { detailed theoretical } \\
\text { framework on the } \\
\text { subject. }\end{array}$ & $\begin{array}{l}\text { A very detailed } \\
\text { theoretical reference } \\
\text { on the subject. }\end{array}$ \\
\hline $\begin{array}{c}\text { C3: Did the article } \\
\text { measure the amount of } \\
\text { food wasted in university } \\
\text { restaurants? }\end{array}$ & $\begin{array}{c}\text { No measurements } \\
\text { made. }\end{array}$ & - & $\begin{array}{c}\text { Measurements } \\
\text { made. }\end{array}$ \\
\hline $\begin{array}{c}\text { C4: Did the article clearly } \\
\text { describe the research } \\
\text { method used? }\end{array}$ & No description. & $\begin{array}{l}\text { Superficial } \\
\text { description. }\end{array}$ & Clear description. \\
\hline $\begin{array}{l}\text { C5: Did the article propose } \\
\text { alternatives for food waste } \\
\text { management in university } \\
\text { restaurants? }\end{array}$ & $\begin{array}{c}\text { No alternatives } \\
\text { proposed. }\end{array}$ & $\begin{array}{c}\text { A few alternatives } \\
\text { proposed. }\end{array}$ & $\begin{array}{c}\text { Many alternatives } \\
\text { proposed. }\end{array}$ \\
\hline $\begin{array}{l}\text { C6: Did the article } \\
\text { describe its limitations and } \\
\text { make suggestions for } \\
\text { future research? }\end{array}$ & $\begin{array}{l}\text { Did not describe } \\
\text { its limitations or } \\
\text { make suggestions. }\end{array}$ & $\begin{array}{c}\text { Superficially } \\
\text { described its } \\
\text { limitations and } \\
\text { made suggestions. }\end{array}$ & $\begin{array}{l}\text { Clearly described its } \\
\text { limitations and } \\
\text { made future } \\
\text { suggestions. }\end{array}$ \\
\hline
\end{tabular}


The usefulness and relevance of each study were analyzed by totaling the results for the criteria. The results were then divided into three classifications. If a study fulfilled one of the usefulness/relevance criteria, a score of +2 points was awarded for this criterion. If a study partially met one of the criteria, a score of +1 was awarded for that criterion. Finally, if a study did not meet a quality criterion, a score of +0 points was assigned to that criterion.

In this way, it can be inferred that, with respect to the six usefulness/relevance criteria described in this SLR, the highest possible score for an analyzed study would be 12 points (or $6 \times 2$ ), while the lowest possible result would be 0 points (or $6 \times 0$ ). The usefulness/relevance of each study was considered high if it obtained a score equal to or greater than 6 . Works with scores of 5 points were considered average quality, while those that obtained a sum less than 5 points were considered low quality, and, therefore, discarded. Based upon this step, 21 articles were selected for final reading and information collection (Phase 8).

iii) Stage III: documentation and results

The data collected from each of the 21 articles in Phase 8 were placed in an extraction form (Phase 9), based on previous studies (Sargeant et al., 2005; Ahmed et al., 2018, Samadi \& Kassou, 2016) (Appendix B).

At this stage, bibliometric and content analysis (Phase 10) was carried out to obtain an overview of the distribution of studies over time, the periodicals in which they were published, the research methods used, and the applications of the studies (storage, preparation or consumption). The second part consisted of presenting a summary of the context of the 21 final articles (Phase 11), seeking to answer the two research questions stipulated in the research protocol (Stage I).

In relation to the research methods used in the selected articles, this SLR adopted the six categories proposed by Filippini (1997): survey, case study, action research, modeling or simulation, experiment or quasi-experimental, and theoretical/conceptual.

To help answer the research questions, QDA Miner® software was used, which is specifically for performing qualitative analysis. Through the reading of the documents, codes were created that allowed the selection of fragments in the texts and that allowed the identification of the two categories mentioned in questions Q1 and Q2: causes and interventions. Table 4 presents a summary of the phases in Stages I, II and III.

Table 4. Detailing the steps during this SLR.

\begin{tabular}{|c|c|c|c|c|}
\hline Stages & Description & Phases & Steps & $\begin{array}{l}\text { Selected } \\
\text { papers }\end{array}$ \\
\hline \multirow{3}{*}{$\begin{array}{l}\text { Stage I: } \\
\text { Planning }\end{array}$} & \multirow{3}{*}{$\begin{array}{l}\text { Conduction of a } \\
\text { scope review, } \\
\text { seeking an } \\
\text { overview of the } \\
\text { subject. }\end{array}$} & \multirow{2}{*}{$\begin{array}{l}\text { 1) Determination } \\
\text { of the } Q 1 \text { and } Q 2 \\
\text { problems and the } \\
\text { research } \\
\text { objective. }\end{array}$} & $\begin{array}{c}\text { 1.1) Searches in } \\
\text { databases } \\
\text { (Scopus, Web of } \\
\text { Science, Scielo, } \\
\text { Google Scholar } \\
\text { etc.). }\end{array}$ & \multirow[t]{2}{*}{-} \\
\hline & & & $\begin{array}{l}\text { 1.2) Delimitation } \\
\text { of the constructs } \\
\text { and keywords. }\end{array}$ & \\
\hline & & $\begin{array}{l}\text { 2) Development of } \\
\text { a review protocol. }\end{array}$ & $\begin{array}{l}\text { 2.1) Definition of } \\
\text { the search } \\
\text { expression for } \\
\text { databases and } \\
\text { the selection } \\
\text { criteria (type of } \\
\text { document, }\end{array}$ & - \\
\hline
\end{tabular}


Table 4. Continued...

\begin{tabular}{|c|c|c|c|c|}
\hline Stages & Description & Phases & Steps & $\begin{array}{l}\text { Selected } \\
\text { papers }\end{array}$ \\
\hline & & & $\begin{array}{l}\text { readability in full } \\
\text { and language). }\end{array}$ & \\
\hline \multirow{9}{*}{$\begin{array}{l}\text { Stage II: } \\
\text { Conduction }\end{array}$} & \multirow{9}{*}{$\begin{array}{c}\text { Searches } \\
\text { performed in } \\
\text { selected } \\
\text { databases: } \\
\text { Engineering } \\
\text { Village, ProQuest, } \\
\text { Scopus, Web of } \\
\text { Science e Scielo. } \\
\text { Utilization of the } \\
\text { Start }{ }^{\circledR} \text { software as } \\
\text { a conduction tool. }\end{array}$} & $\begin{array}{l}\text { 3) Selection of the } \\
\text { studies. }\end{array}$ & $\begin{array}{l}\text { Initial search in } \\
\text { the selected } \\
\text { databases. }\end{array}$ & 352 \\
\hline & & \multirow{3}{*}{$\begin{array}{l}\text { 4) Application of } \\
\text { the selection } \\
\text { criteria. }\end{array}$} & $\begin{array}{l}\text { 4.1) Selection by } \\
\text { document. }\end{array}$ & 288 \\
\hline & & & $\begin{array}{l}\text { 4.2) Selection by } \\
\text { language. }\end{array}$ & 278 \\
\hline & & & $\begin{array}{l}\text { 4.3) Deletion of } \\
\text { duplicate } \\
\text { documents. }\end{array}$ & 220 \\
\hline & & $\begin{array}{l}\text { 5) Quantitative } \\
\text { evaluation. }\end{array}$ & $\begin{array}{l}\text { Sorting the } \\
\text { reading priority. }\end{array}$ & 220 \\
\hline & & \multirow{2}{*}{$\begin{array}{l}\text { 6) Application of } \\
\text { selection filters. }\end{array}$} & $\begin{array}{l}\text { 6.1) Reading of } \\
\text { title, abstract and } \\
\text { keywords. }\end{array}$ & 92 \\
\hline & & & $\begin{array}{l}\text { 6.2) Reading of } \\
\text { introduction and } \\
\text { conclusion. }\end{array}$ & 39 \\
\hline & & $\begin{array}{l}\text { 7) Qualitative } \\
\text { evaluation of the } \\
\text { studies, } \\
\text { establishing C1 to } \\
\text { C6 criteria. }\end{array}$ & $\begin{array}{l}\text { Complete } \\
\text { reading. }\end{array}$ & 21 \\
\hline & & $\begin{array}{l}\text { 8) Extraction of } \\
\text { data. }\end{array}$ & $\begin{array}{l}\text { Complete } \\
\text { reading. }\end{array}$ & 21 \\
\hline \multirow[b]{2}{*}{$\begin{array}{l}\text { Stage III: } \\
\text { Documentation } \\
\text { and Results }\end{array}$} & \multirow{2}{*}{$\begin{array}{l}\text { Reading and } \\
\text { analysis of } \\
\text { documents. To } \\
\text { help answer } \\
\text { questions Q1 and } \\
\text { Q2, QDA Miner® } \\
\text { software was used, } \\
\text { which is specific } \\
\text { for performing } \\
\text { qualitative } \\
\text { analysis. }\end{array}$} & $\begin{array}{l}\text { 9) Synthesis of } \\
\text { data. }\end{array}$ & $\begin{array}{l}\text { Development of } \\
\text { an extraction } \\
\text { form for each } \\
\text { selected article. }\end{array}$ & 21 \\
\hline & & $\begin{array}{l}10) \\
\text { Documentation } \\
\text { and } \\
\text { implementation of } \\
\text { recommendations. }\end{array}$ & $\begin{array}{l}\text { Bibliometric and } \\
\text { content analysis. }\end{array}$ & 21 \\
\hline
\end{tabular}

\section{Results}

The publications analyzed intensified after 2015, the year in which four studies were registered, showing the relevance of the theme in recent years. Four articles were also published in 2016. By 2017, this number had risen to five articles.

The 21 papers analyzed were published in 16 journals and 3 conferences. Table 5 shows the distribution of journals and conferences and the number of articles published in each. In terms of the number of publications, only the British Food Journal and Waste Management had more than one publication. The other journals/conferences contributed only one publication. 
Table 5. Journals/Conferences in which the articles were published.

\begin{tabular}{|c|c|}
\hline Journals & Number of papers \\
\hline British Food Journal & 2 \\
\hline Waste Management & 2 \\
\hline American Journal of Agricultural Economics & 1 \\
\hline Appetite & 1 \\
\hline Applied Mechanics \& Materials & 1 \\
\hline Environmental Engineering and Management Journal & 1 \\
\hline Holos & 1 \\
\hline International Journal of Consumer Studies & 1 \\
\hline Journal of Academy of Nutrition and Dietetics & 1 \\
\hline Journal of Culinary Science \& Technology & 1 \\
\hline Journal of Foodservice Business Research & 1 \\
\hline Journal of Hunger \& Environmental Nutrition & 1 \\
\hline Pakistan Journal of Nutrition & 1 \\
\hline Public Health Nutrition & 1 \\
\hline South African Journal of Clinical Nutrition & 1 \\
\hline Waste Management \& Research & 1 \\
\hline Conferences & Number of papers \\
\hline $\begin{array}{l}\text { III International Conference on Wastes: Solutions, Treatments, and } \\
\text { Opportunities }\end{array}$ & 1 \\
\hline IOP Conference Series: Materials Science and Engineering & 1 \\
\hline
\end{tabular}

In $62 \%$ of the articles analyzed, case study was the method used. Experimental or quasi-experimental designs were used in $19 \%$ of the investigations evaluated, and surveys appeared as a method in $9 \%$. Theoretical articles and action research applications were used in equal percentages in the remaining works.

Table 6 presents a synthesis of the data on the 21 articles selected. It presents the following information: year of publication; authors; scores received during the usefulness/relevance evaluation (Phase 7; applications, showing whether the work concentrated on studying food waste in storage, preparation or consumption; and finally, whether the study measured food waste in university restaurants during consumption.

Table 6. Summary of selected papers.

\begin{tabular}{|c|c|c|c|c|c|c|}
\hline \multirow{2}{*}{ Authors } & \multirow{2}{*}{ Score } & \multicolumn{3}{|c|}{ Application } & \multicolumn{2}{|c|}{ Measurement } \\
\hline & & Storage & Preparation & Consumption & Yes & No \\
\hline Painter et al. (2016) & 12 & & & $\times$ & $x$ & \\
\hline Betz et al. (2015) & 11 & $x$ & $x$ & $x$ & $x$ & \\
\hline Lorenz et al. (2017) & 10 & & & $x$ & & $x$ \\
\hline Qi \& Roe (2017) & 10 & & & $x$ & $x$ & \\
\hline Kim \& Morawski (2012) & 9 & & & $x$ & $x$ & \\
\hline $\begin{array}{c}\text { Thiagarajah \& Getty } \\
(2013)\end{array}$ & 9 & & & $x$ & $x$ & \\
\hline Al-Domi et al. (2011) & 9 & & & $x$ & $x$ & \\
\hline Marais et al. (2017) & 9 & & $x$ & $x$ & $x$ & \\
\hline Zotesso et al. (2016) & 9 & $x$ & $x$ & $x$ & $x$ & \\
\hline
\end{tabular}


Table 6. Continued...

\begin{tabular}{|c|c|c|c|c|c|c|}
\hline \multirow{2}{*}{ Authors } & \multirow{2}{*}{ Score } & \multicolumn{3}{|c|}{ Application } & \multicolumn{2}{|c|}{ Measurement } \\
\hline & & Storage & Preparation & Consumption & Yes & No \\
\hline Kuo \& Shih (2016) & 9 & & & $x$ & $x$ & \\
\hline $\begin{array}{l}\text { Lorenz \& Langen } \\
\text { (2018) }\end{array}$ & 9 & & & $x$ & & $x$ \\
\hline Mirosa et al. (2016) & 8 & & & $x$ & & $x$ \\
\hline Alias et al. (2017) & 8 & & & $x$ & $x$ & \\
\hline $\begin{array}{c}\text { Jagau \& Vyrastekova } \\
(2017)\end{array}$ & 8 & & & $x$ & & $x$ \\
\hline Babich \& Smith (2010) & 7 & & & $x$ & $x$ & \\
\hline Carneiro (2014) & 7 & $x$ & $x$ & $x$ & $x$ & \\
\hline Youngs et al. (1983) & 7 & $x$ & $x$ & $x$ & & $x$ \\
\hline Zawawi et al. (2015) & 6 & $x$ & $x$ & $x$ & $x$ & \\
\hline Wansink \& Just (2015) & 6 & & & $x$ & & $x$ \\
\hline Rizk \& Perão (2015) & 6 & $x$ & $x$ & $\times$ & $x$ & \\
\hline Bankson (2009) & 5 & & & $x$ & & $x$ \\
\hline
\end{tabular}

The articles that carried out measurements of waste numbered 14 (see Table 5). The location of the restaurants, types of meal and amounts of wasted food are shown in Table 7.

Table 7. Study location and amount of wasted food.

\begin{tabular}{|c|c|c|c|c|c|}
\hline \multirow{2}{*}{ Reference } & \multirow{2}{*}{ Location } & \multicolumn{3}{|c|}{ Type of meal } & \multirow{2}{*}{ Amount } \\
\hline & & Breakfast & Lunch & Dinner & \\
\hline Painter et al. (2016) & Rhodes University & $x$ & $x$ & $x$ & $555 \mathrm{~g} /$ person/day \\
\hline $\begin{array}{l}\text { Zotesso et al. } \\
\quad(2016)\end{array}$ & $\begin{array}{c}\text { State University of } \\
\text { Maringá }\end{array}$ & $x$ & $x$ & $x$ & $483 \mathrm{~g} /$ person/day \\
\hline Alias et al. $(2017)^{2}$ & $\begin{array}{c}\text { Universiti Tun } \\
\text { Hussein Onn } \\
\text { Malaysia }\end{array}$ & $x$ & $x$ & $x$ & $247.9 \mathrm{~kg} /$ day \\
\hline Rizk \& Perão (2015) & $\begin{array}{c}\text { São Paulo State } \\
\text { University }\end{array}$ & & $x$ & & $151.7 \mathrm{~g} /$ person/day \\
\hline $\begin{array}{c}\text { Thiagarajah \& Getty } \\
(2013)\end{array}$ & Indiana University & & $x$ & $x$ & $124 \mathrm{~g} /$ person/day \\
\hline $\begin{array}{l}\text { Zawawi et al. } \\
(2015)^{2}\end{array}$ & $\begin{array}{l}\text { Universiti Malaysia } \\
\text { Sarawak }\end{array}$ & $x$ & $x$ & $x$ & $115.95 \mathrm{~kg} / \mathrm{day}$ \\
\hline $\begin{array}{c}\text { Kim \& Morawski } \\
(2012)\end{array}$ & American University & & $x$ & $x$ & $111 \mathrm{~g} /$ person/day \\
\hline Kuo \& Shih $(2016)^{1}$ & - & & & $x$ & 94.3g/person/day \\
\hline Betz et al. $(2015)^{1}$ & - & & $x$ & & $91.23 \mathrm{~g} /$ person/day \\
\hline $\begin{array}{c}\text { Babich \& Smith } \\
(2010)\end{array}$ & $\begin{array}{l}\text { Southern Illinois } \\
\text { University }\end{array}$ & $x$ & $x$ & $x$ & $88.5 \mathrm{~g} /$ person/day \\
\hline Carneiro (2014) & $\begin{array}{l}\text { Federal University of } \\
\text { Rio Grande do Norte }\end{array}$ & $x$ & $x$ & $x$ & 85.7g/person/day \\
\hline $\begin{array}{l}\text { Al-Domi et al. } \\
\qquad(2011)\end{array}$ & University of Jordan & & $x$ & & $75 \mathrm{~g} /$ person/day \\
\hline Marais et al. (2017) & $\begin{array}{l}\text { Stellenbosch } \\
\text { University }\end{array}$ & & $x$ & & 58g/person/day \\
\hline Qi \& Roe (2017) ${ }^{1}$ & - & & $x$ & & $40.8 \mathrm{~g} /$ person/day \\
\hline
\end{tabular}

${ }^{1}$ Location not provided. ${ }^{2}$ Number of daily meals served not provided. 
Among the keywords used in the selected articles, Table 8 presents those that were most cited and also those that were more related to the theme of this work. Thus, "food waste" was the most-cited expression (38\%), followed by "plate waste," "restaurant," "food service industry" and "composting," which were found in three articles (14\%). The other keywords were found in only one article; it is worth noting that the majority of these keywords presented synonyms, radicals, complements, etc.

Table 8. Keywords used in selected papers.

\begin{tabular}{|c|c|c|c|c|c|}
\hline Keywords & $\%$ & Keywords & $\%$ & Keywords & $\%$ \\
\hline Food waste & $38 \%$ & Food choice & $5 \%$ & $\begin{array}{l}\text { Restaurant waste } \\
\text { composition }\end{array}$ & $5 \%$ \\
\hline Plate waste & $14 \%$ & Food losses & $5 \%$ & Solid waste composition & $5 \%$ \\
\hline Restaurant & $14 \%$ & $\begin{array}{l}\text { Food waste } \\
\text { management }\end{array}$ & $5 \%$ & Solid waste generation & $5 \%$ \\
\hline Food service industry & $14 \%$ & $\begin{array}{l}\text { Food waste } \\
\text { prevention }\end{array}$ & $5 \%$ & Sustainability & $5 \%$ \\
\hline Composting & $14 \%$ & Foodservice & $5 \%$ & Sustainable & $5 \%$ \\
\hline $\begin{array}{l}\text { Behavioral } \\
\text { intervention }\end{array}$ & $5 \%$ & Gender & $5 \%$ & Sustainable consumption & $5 \%$ \\
\hline Catering & $5 \%$ & Information campaign & $5 \%$ & Sustainable foodservice & $5 \%$ \\
\hline Consumer behavior & $5 \%$ & Intervention & $5 \%$ & Tray removal & $5 \%$ \\
\hline Consumption & $5 \%$ & Leftovers & $5 \%$ & Trayless dining & $5 \%$ \\
\hline Customer services & $5 \%$ & Meals & $5 \%$ & Trayless system & $5 \%$ \\
\hline Dining halls & $5 \%$ & Nutrition education & $5 \%$ & Universities interventions & $5 \%$ \\
\hline Eating behavior & $5 \%$ & Out-of-home & $5 \%$ & University dining & $5 \%$ \\
\hline $\begin{array}{c}\text { Education and } \\
\text { coercion }\end{array}$ & $5 \%$ & $\begin{array}{l}\text { Out-of-home } \\
\text { consumption }\end{array}$ & $5 \%$ & University dining hall & $5 \%$ \\
\hline Emotions & $5 \%$ & Quality & $5 \%$ & Waste disposal & $5 \%$ \\
\hline $\begin{array}{c}\text { Environmental } \\
\text { damage }\end{array}$ & $5 \%$ & Recycling & $5 \%$ & Waste management & $5 \%$ \\
\hline Food & $5 \%$ & Rescue system & $5 \%$ & Waste management plan & $5 \%$ \\
\hline $\begin{array}{l}\text { Food and food } \\
\text { industries }\end{array}$ & $5 \%$ & $\begin{array}{l}\text { Restaurant food } \\
\text { waste }\end{array}$ & $5 \%$ & & \\
\hline
\end{tabular}

Table 9 presents 13 causes of wastage and 14 interventions that were found in the 21 documents selected, and which can be used to evaluate and reduce food waste in university restaurants. Both causes and interventions are described briefly and placed according to the number of documents that address them. 
Table 9. Causes of waste and interventions for its reduction in university restaurants.

\begin{tabular}{|c|c|c|c|c|c|c|c|c|c|c|c|c|c|c|c|c|c|c|c|c|c|c|c|c|}
\hline & & 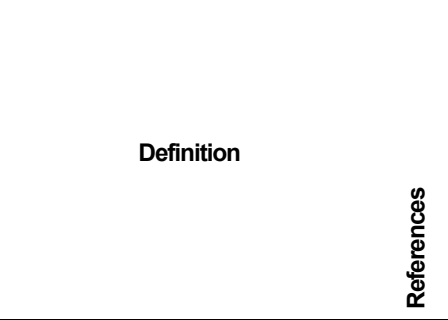 & 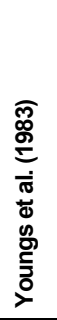 & 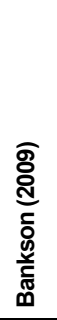 & 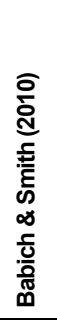 & 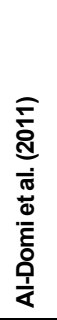 & 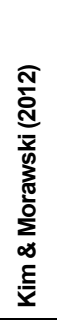 & 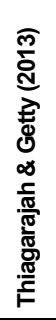 & 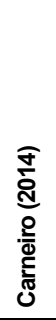 & 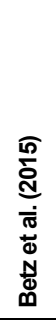 & 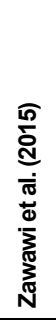 & 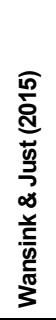 & 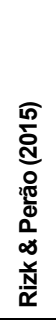 & 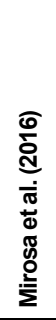 & 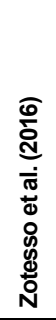 & 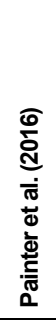 & 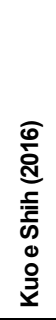 & 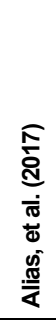 & 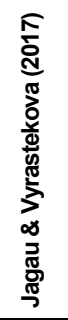 & 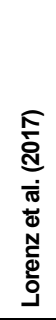 & 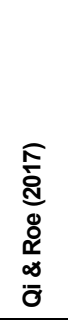 & 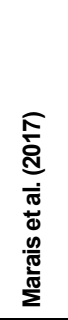 & 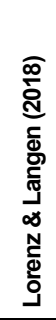 & 횽 \\
\hline & Portion size & $\begin{array}{l}\text { The size of the portion that is served } \\
\text { during the meal influences the amount of } \\
\text { food consumed and, therefore, wasted. }\end{array}$ & $\bullet$ & & & $\bullet$ & & & & $\bullet$ & & & & $\bullet$ & & $\bullet$ & $\bullet$ & & $\bullet$ & $\bullet$ & & $\bullet$ & $\bullet$ & 10 \\
\hline & Quality & $\begin{array}{l}\text { Consumer perception of the quality of the } \\
\text { food offered by restaurants. }\end{array}$ & $\bullet$ & & & & & & & $\bullet$ & & & & $\bullet$ & & $\bullet$ & $\bullet$ & & & $\bullet$ & & $\bullet$ & $\bullet$ & 8 \\
\hline & Price & The price of meals influences food waste. & & & & $\bullet$ & & & & $\bullet$ & & & & & & & & $\bullet$ & $\bullet$ & $\bullet$ & $\bullet$ & & $\bullet$ & 7 \\
\hline & Emotion & $\begin{array}{l}\text { Emotional factors, such as stress, } \\
\text { contribute to the food waste. }\end{array}$ & & & & $\bullet$ & & & & $\bullet$ & & & $\bullet$ & $\bullet$ & & & & & $\bullet$ & & & $\bullet$ & $\bullet$ & 7 \\
\hline & Palatability & $\begin{array}{l}\text { Factors such as taste, odor, appearance } \\
\text { and/or texture may influence consumer's } \\
\text { behavior regarding food waste. }\end{array}$ & & & & & & & & $\bullet$ & & & & $\bullet$ & & $\bullet$ & & & $\bullet$ & $\bullet$ & & $\bullet$ & $\bullet$ & 7 \\
\hline & $\begin{array}{l}\text { Preparation/ } \\
\text { Cooking }\end{array}$ & $\begin{array}{l}\text { The way which food is prepared or cooked } \\
\text { influences the amount of food wasted. }\end{array}$ & $\bullet$ & & & & & & & $\bullet$ & & & $\bullet$ & & $\bullet$ & & & & & $\bullet$ & & $\bullet$ & & 6 \\
\hline & Menu & $\begin{array}{l}\text { Menu choices that do not satisfy } \\
\text { consumers contribute to food waste. }\end{array}$ & & & $\bullet$ & & & & & & & & & $\bullet$ & $\bullet$ & & $\bullet$ & & & $\bullet$ & & & $\bullet$ & 6 \\
\hline & Time & $\begin{array}{l}\text { The longer consumers have to finish meal, } \\
\text { the lower the food waste. }\end{array}$ & & & & $\bullet$ & & & & $\bullet$ & & & & $\bullet$ & & $\bullet$ & & & & $\bullet$ & & & $\bullet$ & 6 \\
\hline & Satiety & $\begin{array}{l}\text { Satiety contributes to meals not being } \\
\text { completely consumed, leading to food } \\
\text { waste. }\end{array}$ & & $\bullet$ & & & & & & $\bullet$ & & & & $\bullet$ & & $\bullet$ & & & & $\bullet$ & & & & 5 \\
\hline & Storage & $\begin{array}{l}\text { Improper storage of food leads to food } \\
\text { waste. }\end{array}$ & $\bullet$ & & & & & & & $\bullet$ & & & & & $\bullet$ & & & & & & & & & 3 \\
\hline & Service & $\begin{array}{l}\text { Type of service (i.e. self-service, a la carte, } \\
\text { etc.) contributes to food waste. }\end{array}$ & $\bullet$ & & & & & & & & & & & & & & & & & $\bullet$ & & & & 2 \\
\hline \multirow{2}{*}{ 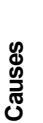 } & Overbuying & $\begin{array}{l}\text { Overbuying foods can lead to non-use } \\
\text { and, consequently, waste. }\end{array}$ & $\bullet$ & & & & & & & & & & & & & & & & & & & & & 1 \\
\hline & Security & $\begin{array}{l}\text { Referencing quantity of food served, as to } \\
\text { ensure satiety. }\end{array}$ & & & & & & & & & & & & $\bullet$ & & & & & & & & & & 1 \\
\hline
\end{tabular}


Table 9. Continued...

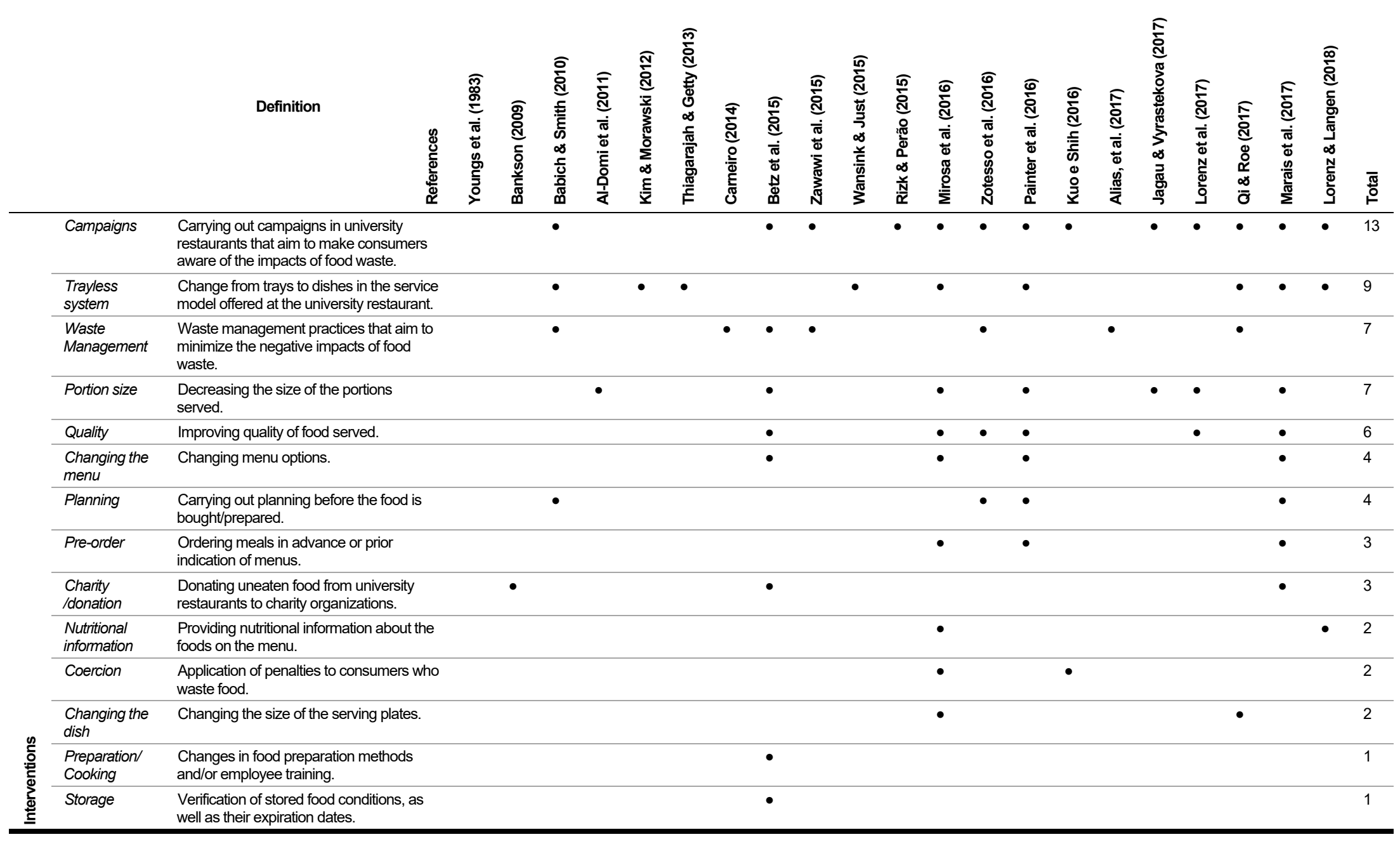




\section{Discussion}

\subsection{Discussion of causes}

The most significant cause of food waste in university restaurants was portion size (Youngs et al., 1983; Al-Domi et al., 2011; Betz et al., 2015; Mirosa et al., 2016; Painter et al., 2016; Kuo \& Shih, 2016; Jagau \& Vyrastekova, 2017; Lorenz et al., 2017; Marais et al., 2017; Lorenz \& Langen, 2018). Changes in portion sizes can influence consumer eating behavior without them noticing. Individuals tend to eat larger amounts of food when different components of the meal are served together, compared to portions served separately on smaller dishes. Thus, larger portion sizes lead to unconsciously increased food intake.

Another cause was quality, commented on in eight articles. Youngs et al. (1983), Betz et al. (2015), Lorenz et al. (2017) and Lorenz \& Langen (2018) suggested that foods considered of poor quality result in greater amounts of waste. Mirosa et al. (2016), Painter et al. (2016), Kuo \& Shih (2016) and Marais et al. (2017) pointed out that students attributed waste to perceived poor food quality.

A third cause to be considered was the price of meals, commented on in seven articles. In addition influencing students' decisions to dine at college restaurants, low price was pointed out as a reason for waste (Al-Domi et al., 2011; Betz et al., 2015; Alias et al., 2017; Jagau \& Vyrastekova, 2017; Lorenz et al., 2017; Qi \& Roe, 2017; Lorenz \& Langen; 2018).

The fourth most-cited cause was emotion, which was mentioned in seven articles (AlDomi et al., 2011; Betz et al., 2015; Rizk \& Perão (2015); Mirosa et al., 2016; Jagau \& Vyrastekova, 2017; Marais et al., 2017; Lorenz \& Langen 2018). Betz et al. (2015), Mirosa et al. (2016), Marais et al. (2017) and Lorenz \& Langen (2018) looked at aspects that influenced students to accept the menu or not to completely consume what was served, and concluded that accepting or rejecting food was linked to stress. Students with high levels of stress tended to waste more food.

Rizk \& Perão (2015) associated food waste with climate factors. According to these authors, hot dishes tend to be rejected on days of high temperatures. Jagau \& Vyrastekova (2017) investigated how emotions were related to the behavior of wasting food after a campaign against waste. The authors found that in contexts such as this, the social emotions of guilt and shame were related to consumers' intentions to avoid wasting food.

The palatability of foods, which is also associated with quality and involves the visual appearance, smell, texture, taste and temperature of the food, was cited in seven papers (Betz et al., 2015; Mirosa et al., 2016; Painter et al., 2016; Jagau \& Vyrastekova, 2017; Lorenz et al., 2017; Marais et al., 2017; Lorenz \& Langen, 2018) as one of the major causes of the behavior of rejecting or accepting food.

Youngs et al. (1983), Betz et al. (2015), Zotesso et al. (2016), Lorenz et al. (2017) and Marais et al. (2017) found that food waste also occurs during preparation/cooking. This waste stems from inefficient cooking/food handling techniques, which also lead to excessive nutrient losses caused, for example, by overheating (Youngs et al., 1983). In addition, waste can occur due to over-preparation or peeling some foods, such as fruits and vegetables, which result in significant amounts of edible food being discarded (Youngs et al., 1983). 
Cited in six studies (Babich \& Smith, 2010; Mirosa et al., 2016; Zotesso et al., 2016; Kuo \& Shih, 2016; Lorenz et al., 2017; Lorenz \& Langen, 2018), the composition of menus was also considered to be an important cause of food waste.

Six studies (Al-Domi et al., 2011; Betz et al., 2015; Mirosa et al., 2016; Painter et al., 2016; Lorenz et al., 2017; Lorenz \& Langen, 2018) suggested that time limitations can, independently of other factors, also have a causal relationship with food waste during consumption. According to Al-Domi et al. (2011), time was one of the fundamental causes that motivated students at the University of Jordan (Jordan) to choose the university restaurant for their meals. Students who had could take longer to consume their meal wasted less food.

Another cause for food wastage in university restaurants was satiety before the end of the meal. This cause was mentioned in five papers (Bankson, 2009; Betz et al., 2015; Mirosa et al., 2016; Painter et al., 2016; Lorenz et al., 2017).

The inefficient storage of food in university restaurants was cited in three documents as a cause that can lead to waste from pest infestation, bacterial growth and fungi (Youngs et al., 1983; Betz et al., 2015; Zotesso et al., 2016). According to Youngs et al. (1983), damaged food may be unacceptable to consumers, as in the case of fruit. Betz et al. (2015) commented that waste as a consequence of inefficient storage also occurs with foods that were prepared to serve in buffets and were stored for more than a day after preparation, such as salads.

The model for service offered by restaurants also influences the amount of wasted food (Youngs et al., 1983; Lorenz et al., 2017). Self-service and more flexible menu services produce smaller amounts of wasted food than standardized meals.

Youngs et al. (1983) found that storage and preparation/cooking are related to another cause that encourages food wastage in college restaurants, which is overbuying. According to the authors, buying of excess food may cause inability to use purchased food raw materials before they deteriorate, resulting in waste when discarded. Rizk \& Perão (2015) indicated that the amount of food wasted could be related to the amount of food prepared. This relationship was considered because preparation planning in the analyzed restaurant was carried out according to the average number of meals sold per day. However, the frequency of meal consumption varied according to differences between supply and demand.

Finally, another cause identified in the literature involving food wastage in university restaurants, as a consequence of consumer behavior, was security, which was pointed out in the work of Mirosa et al. (2016). According to the survey conducted by Mirosa et al. (2016), the students mentioned that they felt the need to order large quantities of food, making sure there was enough food even if it meant ordering more food than they could actually consume.

\subsection{Intervention discussion}

The implementation of campaigns appeared in thirteen of the selected articles. Babich \& Smith (2010), Rizk \& Perão (2015), Jagau \& Vyrastekova (2017), Lorenz et al. (2017), Marais et al. (2017) and Lorenz \& Langen (2018) considered the implementation of information campaigns as a sustainable way to inform students about the negative impact of food waste. Zawawi et al. (2015) suggested the implementation of campaigns that emphasize the importance of reducing, recycling and reusing. Kuo \& Shih (2016) commented on the importance of efforts by university restaurants to advise consumers to 
take only what they can eat. Usually, large quantities of food are served and there is no extra cost for waste.

Mirosa et al. (2016) pointed out that food waste awareness campaigns are an intervention technique that can be used to inform consumers about damage to food safety and the environment. Qi \& Roe (2017) found that providing information on the negative effects of food waste disposed of directly in landfills significantly reduced the amount of food wasted.

Painter et al. (2016) recommended that this information be discussed during orientation week for new students, offering an opportunity to engage students in the process of minimizing food waste. Simultaneous with these interventions, Betz et al. (2015) suggested the application of a feedback questionnaire to understand the reasons that led consumers to waste food.

Another recommended intervention to reduce waste was the removal of trays. Trayless systems were discussed in nine papers, including as the central objective of some, such as the studies of Kim \& Morawski (2012) and Thiagarajah \& Getty (2013). In these studies, the authors tried to determine how the use of trays can negatively impact the amount of food wasted in university restaurants.

Kim \& Morawski (2012) conducted an experiment to evaluate the effects of tray availability on food waste production at the American University (United States) restaurant. The authors documented a $32 \%$ reduction in waste when trays were not available, suggesting that tray removal is a simple way for universities to reduce their environmental and economic impacts. Similarly, Thiagarajah \& Getty (2013) identified a waste reduction of approximately $23 \mathrm{~g} /$ consumer when comparing a tray system and a trayless system at the Indiana University (U.S.) university restaurant.

Other papers only suggested trayless systems may be an effective way to reduce waste in university restaurants: Babich \& Smith (2010), Wansink \& Just (2015), Mirosa et al. (2016), Painter et al. (2016), Marais et al. (2017), Qi \& Roe (2017) and Lorenz \& Langen (2018).

Interventions involving waste management were pointed out in seven articles. Carneiro (2014) and Zotesso et al. (2016) recommended the implementation of an integrated solid waste management system. Babich \& Smith (2010) and Zawawi et al. (2015) identified the amount of food waste generated, and then calculated the potential energy and profits that could be obtained from the reuse of this waste.

Betz et al. (2015) recommended re-use and recycling, and concluded that energy production through waste and disposal of food in the trash should be the last resort. These authors quantified and analyzed the food waste generated at a university, and verified that composting was the best and most efficient method to manage the waste in six investigated cafeterias.

Qi \& Roe (2017) also suggested composting for food waste management and explored how consumer awareness of environmental impacts is related to consumption and waste. The authors pointed out that consumers tend to waste more when they are told that the waste will be used for composting than when they are told that the waste will be disposed of as trash.

Another intervention was a decrease in portion size (Betz et al., 2015; Al-Domi et al., 2011; Mirosa et al., 2016; Painter et al., 2016; Jagau \& Vyrastekova, 2017; Lorenz et al., 2017; Marais et al., 2017). The results of the literature search indicated that large portion sizes were related to unconscious increases in food consumption and increases in waste left in dishes.

Improving the quality of meals was also pointed out in the research as a way to reduce avoidable waste of food in university restaurants (Betz et al., 2015; Mirosa et al., 2016; 
Zotesso et al., 2016; Painter et al., 2016; Lorenz et al., 2017; Marais et al., 2017). Painter et al. (2016) recommended the implementation of periodic reviews of the quality of the food served in university restaurants as a way to reduce waste.

Similarly, Marais et al. (2017) found that students at the University of Stellenbosch (South Africa) also demanded better quality meals. Zotesso et al. (2016) pointed out that the choice of suppliers influences quality and wastage of food. Therefore, educational institutions should choose suppliers according to pre-established quality standards.

Among the alternatives for quality improvement, the composition of menus was mentioned in the studies of Betz et al. (2015), Mirosa et al. (2016), Painter et al. (2016) and Marais et al. (2017). Betz et al. (2015) mentioned that food wastage is reduced when there are flexible menus. Mirosa et al. (2016), Painter et al. (2016) and Marais et al. (2017) found that students were not satisfied with their menu choices. However, although changing menus was suggested, these authors recommended that the number of options be reduced, so as to result in simplified production planning and decrease of food waste.

Babich \& Smith (2010) and Zotesso et al. (2016) suggested that adequate planning is necessary to reduce the amount of waste in university restaurants. According to Painter et al. (2016), estimating the amount of food wasted in college restaurants helps in planning waste reduction programs. When it comes to food storage and preparation, Babich \& Smith (2010) recommended that the purchase and preparation of food/meals be carried out according to demand forecasts.

In this context, Zotesso et al. (2016) suggested that it is important for the preparation of food for lunch and dinner to be conducted separately since the number of meals served can vary significantly. In addition, this allows the amount of food needed for dinner to be predicted, based on the number of meals served at lunch. Marais et al. (2017) suggested that regular training on correct methods of preparation should be made available to restaurant staff, minimizing avoidable and potentially avoidable waste.

Pre-ordering was also one of the interventions, and was cited in the studies of Mirosa et al. (2016), Painter et al. (2016) and Marais et al. (2017). Painter et al. (2016) and Marais et al. (2017) suggested that students could order their meals 48 hours in advance, and could cancel their order within 24 hours before delivery. Mirosa et al. (2016) also suggested that students indicate the foods they would like to consume at the next meal. However, the authors highlighted the risk associated with this action, since consumers' preferences may differ from one day to the next, which could lead to higher amounts of wasted food.

Charity/donations, which is considered a good intervention for the management of food waste, was commented on by Bankson (2009) and Marais et al. (2017), and cited by Betz et al. (2015). Bankson (2009) found that about 250 unconsumed meals were discarded daily in the university restaurant of the University of Virginia. The author recommended that this avoidable waste could be designated to feed a poor community, thereby improving the institution's sustainability policy. The donation of leftover food to organizations or projects to combat hunger was also cited as an option for reducing waste in the university restaurant of Stellenbosch University (South Africa) (Marais et al., 2017). However, the authors commented on the need for close collaboration between the institution's restaurant representatives and the beneficiaries.

Another similar initiative is providing nutritional information on foods available on menus. Mirosa et al. (2016) noted that whereas nutritional information is generally available in private-sector restaurants, provision of this type of nutritional information does not commonly occur in public feeding services with buffet-style menus. According to Lorenz \& Langen (2018), providing nutritional information may allow consumers to align 
their behaviors according to the interpretation of value-based information, that is, by choosing healthier items.

Another intervention aimed at reducing the waste of food on dishes is coercion. Kuo \& Shih (2016) commented that depending on the goals and consequences, there are several forms of coercion. To defend the use of penalties, restaurants often mention the perishability of food. Mirosa et al. (2016) reported that coercion has recently begun to be used in the private food sector, such as restaurants and cafeterias, and that these initiatives seek to increase the likelihood that consumers will not leave leftover food on their plates. However, the authors advised that precautions be taken before implementing penalties in university restaurants, given the importance of the benefits that consumers derive from the dining experience. The stress could be caused by such penalty systems could compromise these benefits.

The reduction of dish size (changing the dish) in university restaurants was another alternative considered in the studies of Mirosa et al. (2016) and Qi \& Roe (2017). According to Mirosa et al. (2016) and Qi \& Roe (2017), this change in food service configuration is a technique that has been examined in other studies that have explored the industry. Still, according to the authors, smaller dishes provide less space for food layout, that is, increasing the size of the dish implies larger portions and causes more food to be wasted. Thus, reducing the size of the dish contributes to the rationalization of feelings of satiety, since consumers are encouraged to eat less because of the quantity of food served (Mirosa et al., 2016).

Preparation/cooking methods were also cited in a study by Betz et al. (2015) as an alternative to reduce food waste in university restaurants. These authors proposed that strategies should be developed to avoid waste from overproduction. Among these strategies, the reuse of leftovers was highlighted, taking into account applicable legislation; rapid cooling of food in order to avoid the proliferation of microorganisms; and employee training.

Finally, Betz et al. (2015) found that waste during storage was completely avoidable and, therefore, it is important that its management be improved. Regular recommendations for validity/expiration dates and menu adaptations were cited, allowing priorities for food to be used by the expiration date.

\section{Conclusion}

Publications about food waste in university restaurants have shown moderate growth over the last few years, especially from 2015 onwards. However, there are still few published studies on the subject, indicating the lack of new research opportunities.

This literature review identified thirteen causes (portion size, quality, price, emotion, palatability, preparation/cooking, menu, time, satiety, storage, service, overbuying, and security) and 14 possible interventions (campaigns; trayless systems, waste management, portion size, quality, changing menus, planning, pre-ordering, charity/donation, nutritional information, coercion, changing dish size, preparation/cooking, and storage).

All of the selected papers addressed waste during consumption, and some included storage and/or preparation in their analyses. More than half of the selected papers applied the case study method.

The keywords used in the selected articles presented similarities, and the British Food Journal and Waste Management were the only journals that presented more than one publication. A total of 57 authors were identified in the 21 papers, from the United States 
(11 authors present in 6 papers), Malaysia ( 8 authors present in 2 papers), and Brazil ( 7 authors present in 3 papers).

Although efforts were made to maintain a rigorous standard during the execution of the research, this study is not free from limitations, which need to be addressed for future studies. First, even though the review planning was done after several tests that tried to select the best keywords, search expressions, and databases, potentially relevant articles may not have been considered because they had different keywords or were not present in one of the five selected databases. In addition, some studies did not fully disclose their data, making it impossible to extract their information in detail.

The findings of the present study are characterized as exploratory and not definitive, allowing some of the variables to be explored in future research in order to be explored in different contexts and to guarantee their validity.

\section{References}

Ahmed, Y. A., Ahmad, M. N., Ahmad, N., \& Zakaria, N. H. (2018). Social media for knowledgesharing: a systematic literature review. Telematics and Informatics, 37, 72-112. http://dx.doi.org/10.1016/j.tele.2018.01.015.

Al-Domi, H., Al-Rawajfeh, H., Aboyousif, F., Yaghi, S., Mashal, R., \& Fakhoury, J. (2011). Determining and addressing food plate waste in a group of students at the University of Jordan. Pakistan Journal of Nutrition, 10(9), 871-878. http://dx.doi.org/10.3923/pjn.2011.871.878.

Alias, A. R., Mohd Mokhlis, N. A., \& Zainun, N. Y. (2017). Baseline for food waste generation - A case study in Universiti Tun Hussein Onn Malaysia cafeterias. IOP Conference Series: Materials Science and Engineering, 271, 012045. https://doi.org/10.1088/1757899X/271/1/012045.

Alooh, A. O. (2015). Quantifying food plate waste: case study of a university dining facility (Doctoral dissertation). Stellenbosch University, Stellenbosch. Retrieved in 2018, September 15, from http://scholar.sun.ac.za/handle/10019.1/96611

Babich, R., Smith, S. (2010). "Cradle to Grave ": an analysis of sustainable food systems in a university setting. Journal of Culinary Science \& Tencology, 8(4), 180-190. https://doi.org/10.1080/15428052.2010.535747.

Bankson, J. D. (2009). Food rescue system for UVa dining and Charlottesville community. In SIEDS'09 - Systems and Information Engineering Design Symposium (pp. 85-89). USA: IEEE.

Beretta, C., Stoessel, F., Baier, U., \& Hellweg, S. (2013). Quantifying food losses and the potential for reduction in Switzerland. Waste Management (New York, N.Y.), 33(3), 764-773. http://dx.doi.org/10.1016/j.wasman.2012.11.007. PMid:23270687.

Betz, A., Buchli, J., Göbel, C., \& Müller, C. (2015). Food waste in the Swiss food service industry Magnitude and potential for reduction. Waste Management (New York, N.Y.), 35, 218-226. http://dx.doi.org/10.1016/j.wasman.2014.09.015. PMid:25305683.

Birisci, E., \& McGarvey, R. (2018). Production and leftovers usage policies to minimize food waste under uncertain and correlated demand. World Academy of Science, Engineering and Technology. International Journal of Industrial and Manufacturing Engineering, 5(3)

Boschini, M., Falasconi, L., Giordano, C., \& Alboni, F. (2018). Food waste in school canteens: a reference methodology for large-scale studies. Journal of Cleaner Production, 182, 10241032. http://dx.doi.org/10.1016/j.jclepro.2018.02.040.

Briner, R. B., \& Denyer, D. (2012). Systematic review and evidence synthesis as a practice and scholarship tool. Handbook of evidence-based management: companies, classrooms and research (pp. 112-129). Reino Unido: Oxford University Press. 
Buchner, B., Fischler, C., Gustafson, E., Reilly, J., Riccardi, G., Ricordi, C., \& Veronesi, U. (2012). Food waste: causes, impacts and proposals. Parma, Italy: Barilla Center for Food and Nutrition.

Byker, C. J., Farris, A. R., Marcenelle, M., Davis, G. C., \& Serrano, E. L. (2014). Food Waste in a School Nutrition Program After Implementation of New Lunch Program Guidelines. Journal of Nutrition Education and Behavior, 46(5), 406-411. http://dx.doi.org/10.1016/j.jneb.2014.03.009. PMid:24857599.

Carneiro, C. L. (2014). Gerenciamento integrado de resíduos sólidos e sua aplicabilidade em produção de refeições: um diálogo interdisciplinar. Holos., 30, 68-74. http://dx.doi.org/10.15628/holos.2014.1527.

Chalak, A., Abou-Daher, C., Chaaban, J., \& Abiad, M. G. (2016). The global economic and regulatory determinants of household food waste generation: A cross-country analysis. Waste Management (New York, N.Y.), 48, 418-422. http://dx.doi.org/10.1016/j.wasman.2015.11.040. PMid:26680687.

Douglas, F., Sapko, J., Kiezebrink, K., \& Kyle, J. (2015). Resourcefulness, Desperation, Shame, Gratitude and Powerlessness: common themes emerging from a study of food bank use in Northeast Scotland. AIMS Public Health, 2(3), 297-317. http://dx.doi.org/10.3934/publichealth.2015.3.297. PMid:29546112.

Ferreira, M., Liz Martins, M., \& Rocha, A. (2013). Food waste as an index of foodservice quality. British Food Journal, 115(11), 1628-1637. http://dx.doi.org/10.1108/BFJ-03-2012-0051.

Filippini, R. (1997). Operations Management Research: Some Reflections on Evolution. International Journal of Operations \& Production Management, 17(7), 655-670. http://dx.doi.org/10.1108/01443579710175583.

Food and Agriculture Organization - FAO, International Fund for Agricultural Developmen - IFAD, United Nations International Children's Emergency Fund - UNICEF, World Food Programme WFP, \& World Health Organization - WHO. (2018). The State of Food Security and Nutrition in the World 2018. Building climate resilience for food security and nutrition. Rome: FAO.

Food and Agriculture Organization - FAO. (2017). Global and regional overview of food losses and wastage. Rome: FAO.

Gardin Alves, M., \& Ueno, M. (2015). Identificação de fontes de geração de resíduos sólidos em uma unidade de alimentação e nutrição. Revista Ambiente \& Água, 10(4), 874-888. http://dx.doi.org/10.4136/ambi-agua.1640.

Girotto, F., Alibardi, L., \& Cossu, R. (2015). Food waste generation and industrial uses: a review. Waste Management (New York, N.Y.), 45, 32-41. http://dx.doi.org/10.1016/j.wasman.2015.06.008. PMid:26130171.

Graham-Rowe, E., Jessop, D. C., \& Sparks, P. (2015). Predicting household food waste reduction using an extended theory of planned behaviour. Resources, Conservation and Recycling, 101, 194-202. http://dx.doi.org/10.1016/j.resconrec.2015.05.020.

Gustavsson, J., \& Stage, J. (2011). Retail waste of horticultural products in Sweden. Resources, Conservation and Recycling, 55(5), 554-556. http://dx.doi.org/10.1016/j.resconrec.2011.01.007.

Gustavsson, J., Cederberg, C., Sonesson, U., Emanuelsson, A. (2011). The methodology of the FAO study: Global Food Losses and Food Waste-extent, causes and prevention. Rome: FAO.

Jagau, H. L., \& Vyrastekova, J. (2017). Behavioral approach to food waste: an experiment. British Food Journal, 119(4), 882-894. http://dx.doi.org/10.1108/BFJ-05-2016-0213.

Katajajuuri, J. M., Silvennoinen, K., Hartikainen, H., Heikkilä, L., \& Reinikainen, A. (2014). Food waste in the Finnish food chain. Journal of Cleaner Production, 73, 322-329. http://dx.doi.org/10.1016/j.jclepro.2013.12.057.

Kim, K., \& Morawski, S. (2012). Quantifying the impact of going trayless in a university dining hall. Journal of Hunger \& Environmental Nutrition, 7(4), 482-486. http://dx.doi.org/10.1080/19320248.2012.732918. 
Kuo, C., \& Shih, Y. (2016). Gender differences in the effects of education and coercion on reducing buffet plate waste. Journal of Foodservice Business Research, 19(3), 223-235. http://dx.doi.org/10.1080/15378020.2016.1175896.

Lenahan, S., \& Kirwan, K. R. (2001). An analysis of food waste reduction and disposal alternatives in military installations in South Carolina. USA: Hazardous Waste Management Research Fund.

Lorenz, B. A. S., Hartmann, M., \& Langen, N. (2017). What makes people leave their food? The interaction of personal and situational factors leading to plate leftovers in canteens. Appetite, 116, 45-56. http://dx.doi.org/10.1016/j.appet.2017.04.014. PMid:28434893.

Lorenz, B. A., \& Langen, N. (2018). Determinants of how individuals choose, eat and waste: providing common ground to enhance sustainable food consumption out-of-home. International Journal of Consumer Studies, 42(1), 35-75. http://dx.doi.org/10.1111/ijcs.12392.

Marais, M. L., Smit, Y., Koen, N., \& Lötze, E. (2017). Are the attitudes and practices of foodservice managers, catering personnel and students contributing to excessive food wastage at Stellenbosch University? Are the attitudes and practices of foodservice managers, catering personnel and students contrib. The South African Journal of Clinical Nutrition : SAJCN : the Official Journal of the South African Society of Parenteral and Enteral Nutrition and the Association for Dietetics in South Africa, 30(3), 60-67. http://dx.doi.org/10.1080/16070658.2017.1267348.

Martin-Rios, C., Demen-Meier, C., Gössling, S., \& Cornuz, C. (2018). Food waste management innovations in the foodservice industry. Waste Management (New York, N.Y.), 79, 196-206. http://dx.doi.org/10.1016/j.wasman.2018.07.033. PMid:30343746.

Merrow, K., Penzien, P., \& Dubats, T. (2012). Exploring food waste reduction in Campus Dining Halls. Michigan: The Campus as a Living Laboratory.

Mirosa, M., Munro, H., Mangan-Walker, E., \& Pearson, D. (2016). Reducing waste of food left on plates: interventions based on means-end chain analysis of customers in foodservice sector. British Food Journal, 118(9), 2326-2343. http://dx.doi.org/10.1108/BFJ-12-2015-0460.

Nidhra, S., Yanamadala, M., Afzal, W., \& Torkar, R. (2013). Knowledge transfer challenges and mitigation strategies in global software development: a systematic literature review and industrial validation. International Journal of Information Management, 33(2), 333-355. http://dx.doi.org/10.1016/j.jijinfomgt.2012.11.004.

Nightingale, A. (2009). A guide to systematic literature reviews. Surgery, 27, 381-384. http://dx.doi.org/10.1016/j.mpsur.2009.07.005.

Painter, K., Thondhlana, G., \& Kua, H. W. (2016). Food waste generation and potential interventions at Rhodes University, South Africa. Waste Management (New York, N.Y.), 56, 491-497. http://dx.doi.org/10.1016/j.wasman.2016.07.013. PMid:27450431.

Papargyropoulou, E., Lozano, R., K. Steinberger, J., Wright, N., \& Ujang, Z. (2014). The food waste hierarchy as a framework for the management of food surplus and food waste. Journal of Cleaner Production, 76, 106-115. http://dx.doi.org/10.1016/j.jclepro.2014.04.020.

Parfitt, J., Barthel, M., \& MacNaughton, S. (2010). Food waste within food supply chains: quantification and potential for change to 2050. Philosophical transactions of the Royal Society of London. Series B, Biological sciences, 365(1554), 3065-3081. http://dx.doi.org/10.1098/rstb.2010.0126. PMid:20713403.

Pirani, S. I., \& Arafat, H. A. (2016). Reduction of food waste generation in the hospitality industry. Journal of Cleaner Production, 132, 129-145. http://dx.doi.org/10.1016/j.jclepro.2015.07.146.

Porpino, G. (2016). Household food waste behavior: avenues for future research. Journal of the Association for Consumer Research, 1(1), 41-51. http://dx.doi.org/10.1086/684528.

Porpino, G., Parente, J., \& Wansink, B. (2015). Food waste paradox: antecedents of food disposal in low income households. International Journal of Consumer Studies, 39(6), 619-629. http://dx.doi.org/10.1111/ijcs.12207. 
Purdam, K., Garratt, E. A., \& Esmail, A. (2015). Hungry? Food insecurity, social stigma and embarrassment in the UK. Sociology, 50(6), 1072-1088. http://dx.doi.org/10.1177/0038038515594092.

Qi, D., \& Roe, B. E. (2017). Foodservice composting crowds out consumer food waste reduction behavior in a dining experiment. American Journal of Agricultural Economics, 99(5), 11591171. http://dx.doi.org/10.1093/ajae/aax050.

Raak, N., Symmank, C., Zahn, S., Aschemann-Witzel, J., \& Rohm, H. (2017). Processing- and product-related causes for food waste and implications for the food supply chain. Waste Management (New York, N.Y.), 61, 461-472. http://dx.doi.org/10.1016/j.wasman.2016.12.027. PMid:28038904.

<conf>Rizk, M. C., \& Perão, B. A. (2015 September 14-16). Diagnosis of food waste generation in a university restaurant. In WASTES 2015 - Solutions, Treatments and Opportunities: Selected papers from the III International Conference on Wastes: Solutions, Treatments and Opportunities. Boca Raton: CRC Press. http://dx.doi.org/10.1201/b18853-45. </conf>

Samadi, E., \& Kassou, I. (2016). The Relationship between IT and supply chain performance: a systematic review and future research. American Journal of Industrial and Business Management, 6, 480-495. http://dx.doi.org/10.4236/ajibm.2016.64044.

Sargeant, J. M., Amezcua, M. D. R., Rajić, A., \& Waddell, L. A. (2005). A guide to conducting systematic reviews in agri-food public health. Guelph, Ontario, Canada: Public Health Agency of Canada.

Schneider, F. (2013). The evolution of food donation with respect to waste prevention. Waste Management (New York, N.Y.), 33(3), 755-763. http://dx.doi.org/10.1016/j.wasman.2012.10.025. PMid:23453166.

Sebbane, M., \& Costa, S. (2018). Food leftovers in workplace cafeterias: an exploratory analysis of stated behavior and actual behavior. Resources, Conservation and Recycling, 136, 88-94. http://dx.doi.org/10.1016/j.resconrec.2018.04.015.

Stöckli, S., Dorn, M., \& Liechti, S. (2018). Normative prompts reduce consumer food waste in restaurants. Waste Management (New York, N.Y.), 77, 532-536. http://dx.doi.org/10.1016/j.wasman.2018.04.047. PMid:29731405.

Thi, N. B. D., Kumar, G., \& Lin, C. (2015). An overview of food waste management in developing countries : current status and future perspective. Journal of Environmental Management, 157, 220-229. http://dx.doi.org/10.1016/j.jenvman.2015.04.022. PMid:25910976.

Thiagarajah, K., \& Getty, V. M. (2013). Impact on plate waste of switching from a tray to a trayless delivery system in a university dining hall and employee response to the switch. Journal of Academy on Nutrition and Dietetics, 113(1), 141-145. https://doi.org/10.1016/j.jand.2012.07.004.

Thyberg, K. L., \& Tonjes, D. J. (2016). Drivers of food waste and their implications for sustainable policy development. Resources, Conservation and Recycling, 106, 110-123. http://dx.doi.org/10.1016/j.resconrec.2015.11.016.

Tranfield, D., Denyer, D., \& Smart, P. (2003). Towards a methodology for developing evidenceinformed management knowledge by means of systematic review. British Journal of Management, 14(3), 207-222. http://dx.doi.org/10.1111/1467-8551.00375.

United Nations. General Assembly. (2015). Resolution adopted by the General Assembly on 25 September 2015. Transforming our world: the 2030 Agenda for Sustainable Development (35 p.). Retrieved in 2018, September 15, from http://www.un.org/ga/search/view_doc.asp?symbol=A/RES/70/1\&Lang=E

Wansink, B., \& Just, D. R. (2015). Trayless cafeterias lead diners to take less salad and relatively more dessert. Public Health Nutrition, 18(9), 1714. http://dx.doi.org/10.1017/S1368980015001172. PMid:25824667. 
Warshawsky, D. N. (2011). Food bank Johannesburg, state, and civil society organisations in postapartheid Johannesburg. Journal of Southern African Studies, 37(4), 809-829. http://dx.doi.org/10.1080/03057070.2011.617947.

Williams, I. D., Schneider, F., \& Syversen, F. (2015). The "food waste challenge" can be solved. Waste Management (New York, N.Y.), 41, 1-2. http://dx.doi.org/10.1016/j.wasman.2015.03.034. PMid:25952983.

Williams, P., \& Walton, K. (2011). Plate waste in hospitals and strategies for change. Eur. J. Clin. Nutr. Met., 6(6), 235-241. http://dx.doi.org/10.1016/j.eclnm.2011.09.006.

WRAP. (2013). The true cost of food waste within hospitality and food service. Quantification of the true cost of food waste in the UK's hospitality and food service sector. Banbury: WRAP.

Wright, T. S. A. (2006). Giving "teeth" to an environmental policy: a Delphi Study at Dalhousie University. Journal of Cleaner Production, 14(9-11), 761-768. http://dx.doi.org/10.1016/j.jclepro.2005.12.007.

Youngs, A. J., Nobis, G., \& Town, P. (1983). Food waste from hotels and restaurants in the U. K. Waste Management \& Research, 1, 295-308. http://dx.doi.org/10.1016/0734-242X(83)900344.

Zawawi, M. H., Rosli, N. A., Bustami, R. A., Mispan, N. H., \& Ramli, M. Z. (2015). Potential of utilizing solid waste generated in UNIMAS West Campus. Applied Mechanics and Materials, 773-774, 1073-1078. http://dx.doi.org/10.4028/www.scientific.net/AMM.773-774.1073.

Zhang, C., Su, H., Baeyens, J., \& Tan, T. (2014). Reviewing the anaerobic digestion of food waste for biogas production. Renewable \& Sustainable Energy Reviews, 38, 383-392. http://dx.doi.org/10.1016/j.rser.2014.05.038.

Zotesso, J., Cossich, E., Colares, L., \& Tavares, C. (2016). Analysis of solid waste generation in a University Cafeteria in Brazil: a case study. Environmental Engineering and Management Journal, 15(10), 2327-2336. http://dx.doi.org/10.30638/eemj.2016.254. 


\section{Appendix A. Protocol of the Systematic Literature Review.}

\begin{tabular}{|c|c|}
\hline \multicolumn{2}{|c|}{ Protocol of the Systematic Literature Review } \\
\hline Title & Food waste in university restaurants \\
\hline \multicolumn{2}{|l|}{ Researchers } \\
\hline Description & $\begin{array}{l}\text { This SLR aimed to identify the studies present in the } \\
\text { literature that deal with food waste in university restaurants. }\end{array}$ \\
\hline \multirow[t]{2}{*}{ Questions } & $\begin{array}{l}\text { Q1: What are the causes that contribute to food waste in } \\
\text { university restaurants? }\end{array}$ \\
\hline & $\begin{array}{l}\text { Q2: What are the interventions that can be or are used in } \\
\text { university restaurants to reduce food waste? }\end{array}$ \\
\hline Population & Studies found in the databases delimited in this research \\
\hline Intervention & $\begin{array}{l}\text { Studies that address food waste in university } \\
\text { restaurants. }\end{array}$ \\
\hline Results & $\begin{array}{l}\text { The hope is that the results of this research will suppor } \\
\text { studies that address the waste of food in university } \\
\text { restaurants. }\end{array}$ \\
\hline Keywords & $\begin{array}{l}\text { Food waste; food wastage; college cafeteria; college } \\
\text { canteen; college restaurant; faculty cafeteria; faculty } \\
\text { canteen; faculty restaurant; dining hall; university cafeteria } \\
\text { university canteen; university restaurant; education sector. }\end{array}$ \\
\hline Criteria for selection of databases: & $\begin{array}{l}\text { Databases that encompass research related to Agrarian } \\
\text { Sciences, Applied Social Sciences, Exact Sciences, Earth } \\
\text { Sciences, and Engineering, etc. }\end{array}$ \\
\hline Languages & Spanish, English or Portuguese. \\
\hline Methods analyzed & $\begin{array}{l}\text { Survey; case study; action research; modeling or } \\
\text { simulation; experimental or quasi-experimental; theoretical- } \\
\text { conceptual. }\end{array}$ \\
\hline Database & $\begin{array}{l}\text { Engineering Village; ProQuest; Scopus; Web of Science } \\
\text { Scielo. }\end{array}$ \\
\hline Selection Criteria & $\begin{array}{l}\text { Must be related to availability, language and documen } \\
\text { type. }\end{array}$ \\
\hline Quantitative evaluation & $\begin{array}{l}\text { Based on keywords found in the titles, abstracts, and } \\
\text { keywords. }\end{array}$ \\
\hline Qualitative evaluation & $\begin{array}{l}\text { Based on the weighting of pre-established questions, } \\
\text { associated with the objective of this research. }\end{array}$ \\
\hline
\end{tabular}




\section{Appendix B. Data extraction form.}

\section{Extraction Form}

Identification code

Title

Authors

Authors' affiliations

Reference

Year of publication

Search location

Journal/Conference

Objective description

Keywords

Language

Spanish

English

Portuguese

Researchers' areas

Agrarian Sciences

Applied Social Sciences

Exact Sciences

Earth Sciences

Engineering

Other

Method used

Survey

Case study

Action research

Modeling or Simulation

Experimental or Quasi-experimental

Theoretical-conceptual

Application of the study

Storage

Preparation

Consumption

Measures food waste?

Yes

No

Qualitative evaluation

C1:

C2:

C3:

C4:

C5:

C6:

TOTAL:

Limitations

Suggestions 